\title{
Are chironomidae (diptera) good indicators of impact in lotic environments?
}

Chironomid larvae are widely distributed, with high diversity and abundance, and exploit a range of habitats and food resources. They are also an important food resource for various groups of aquatic organisms. Therefore, this study aimed to evaluate the spatial and seasonal variations in the composition of diet and genera of Chironomidae larvae in two streams located in south central west region of Brazil, associated with the environmental impact assessment, based on visual, physical and chemical indicators of streams. The contents of the digestive tracts of the most abundant genera were observed and classified into fine detritus, coarse detritus, algae, fungi, or animal material. Dissolved oxygen, conductivity, and incident light, along with the dominance of certain genera, were strong indicators of pollution in the impacted stream. Cluster analysis indicated three trophic groups: 1) generalist detritivores, consuming fine particulate organic matter and making up $82 \%$ of the genera analyzed; 2) predators, which consumed mainly animal material; and 3) specialist shredding detritivores, present only in the less-impacted stream. These results are useful in understanding anthropogenic effects on stream ecosystems.

Keywords: Bioindicator; Macroinvertebrates; Trophic Groups; Tropical Streams; Food Resources.

\section{Chironomidae (diptera) são bons indicadores de impacto em ambientes lóticos?}

\begin{abstract}
Larvas de Chironomidae apresentam ampla distribuição, elevada diversidade e abundância, explorando uma grande variedade de habitats e recursos alimentares. Eles também são uma importante fonte alimentar para diferentes grupos de organismos aquáticos Portanto, este trabalho teve como objetivo avaliar as variações espaciais e sazonais na composição da dieta e gêneros de larvas de Chironomidae em dois riachos localizados na região centro-sul do Brasil, associados à avaliação de impacto ambiental, com base em indicadores visuais, físicos e químicos de riachos. O conteúdo do trato digestivo dos gêneros de Chironomidae mais abundantes foi observado no microscópio invertido e classificado em detritos finos, detritos grosseiros, algas, fungos e material animal. O riacho Água Boa foi classificado como 'impactado' e o riacho Curral de Arame em 'natural' de acordo com o protocolo de avaliação rápida da diversidade de habitats. Os parâmetros físicos e químicos, como oxigênio dissolvido, condutividade e luminosidade, juntamente com a elevada dominância por determinados gêneros de Chironomidae, constituíram fortes indicadores de poluição no riacho impactado. Na análise de agrupamento foi possível observar três grupos tróficos: 1) os detritívoros generalistas, que consumiram matéria orgânica particulada fina, compondo $82 \%$ dos gêneros analisados; 2) os predadores que consumiram principalmente material animal; 3) detritívoros fragmentadores especialistas, presentes apenas no riacho natural. Estes resultados são relevantes para o entendimento dos efeitos antrópicos sobre os ecossistemas de riachos.
\end{abstract}

Palavras-chave: Bioindicadores; Macroinvertebrados; Grupos Tróficos; Riachos Tropicais; Recursos Alimentares.

Topic: Conservação da Biodiversidade

Reviewed anonymously in the process of blind peer.
Received: $12 / 05 / 2020$

Approved: 02/06/2020
Nathaskia Silva Pereira Nunes (iD

Universidade Federal da Grande Dourados, Brasil

http://lattes.cnpq.br/2406137946626729

http://orcid.org/0000-0002-0433-6412

nathaskia.spn@gmail.com

Emerson Machado de Carvalho (iD)

Universidade Federal do Sul da Bahia, Brasil

http://lattes.cnpq.br/7341724276580365

http://orcid.org/0000-0002-4865-6784

carvalho.em@gmail.com

Jelly Makoto Nakagaki (iD

Universidade Estadual de Mato Grosso do Sul, Brasil

http://lattes.cnpq.br/0042478160581657

http://orcid.org/0000-0003-3791-7528

jellyuems@gmail.com

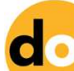

DOI: 10.6008/CBPC2179-6858.2020.004.0010
Referencing this:

NUNES, N. S. P.; CARVALHO, E. M.; NAKAGAKI, J. M.. Are chironomidae (diptera) good indicators of impact in lotic environments?. Revista Ibero Americana de Ciências Ambientais, v.11, n.4, p.113-125, 2020. DOI: http://doi.org/10.6008/CBPC2179-6858.2020.004.0010 


\section{INTRODUCTION}

Water scarcity is one of the greatest challenges facing human society, with changes in the global water cycle intensifying due to climate change (WWAP, 2018). Monitoring water availability is expensive and technically challenging. In this respect, the use of biological communities as indicators offers a cost-effective alternative, since they reflect both temporal and spatial hydrological variability (CAÑEDO-ARGUELLES et al., 2016).

Aquatic macroinvertebrates respond sensitively and predictably to environmental changes with corresponding alterations in community structure and species composition (EADY et al., 2014). Members of the family Chironomidae are widely distributed, abundant, and diverse, with various niches and ecosystem services (CARVALHO et al., 2009; CHOUDHARY et al., 2015; BIASI et al., 2013). Chironomids play a key role in processing organic matter by consuming fine particles and serving as prey for an array of organisms, including other invertebrates, fish, and birds, transferring energy and nutrients to upper trophic levels. They thus have a great influence over productivity and population dynamics of top consumers (SERRA et al., 2016).

Many member species of the Chironomidae have specific adaptations to challenging environments. Some chironomids such as Phaenopsectra flavipes, Rheotanytarsus, and Cladotanytarsus sp. prefer oligotrophic freshwater habitats, while others such as Chironomus sp., Cricotopus bicinctus, and Cricotopus (Isocladius) sylvestris are tolerant of organic contamination (CHAIB et al., 2012). Some can also survive at low oxygen levels; members of the genus Chironomus, for example, carry high levels of haemoglobin as an adaptation for such environments (RAWAL, 2014).

Most studies on chironomid larvae are ecologically oriented, focusing on distribution, abundance, and environmental assessment. The distribution of the chironomid assemblage is determined by abiotic factors, with some species being strongly associated with high levels of pollution (CHAIB et al., 2012; LENCIONI et al., 2012). However, the potential of the Chironomidae as environmental indicators is generally neglected due to their complex taxonomy (CAÑEDO-ARGÜELLES et al., 2016). Approaches based on other characteristics, such as dietary analysis, may be alternatives to evaluate aquatic and biological integrity, without the need for a taxonomic refinement for the group in question.

Previous studies have demonstrated the importance of the Chironomidae family in the food web and the decomposition of organic matter in shallow lakes (REZENDE et al., 2018), tropical streams (CARVALHO et al., 2009; CALLISTO et al., 2013; CHESHIRE et al., 2005; HENRIQUES-OLIVEIRA et al., 2003; MOTTA et al., 2004) and rivers (HELSON et al., 2006), subtropical streams (BIASI et al., 2013), temperate streams (SERRA et al., 2016), and neotropical floodplain (BUTAKKA et al., 2016), among other aquatic environments. The functional feeding groups (FFG) of the Chironomidae reflect changes in water availability and habitat characteristics (CAÑEDO-ARGÜELLES et al., 2016). However, studies on dietary habits are scarce or are described only in the ecological and biological context of the group.

Most chironomid larvae are opportunistic omnivores, feeding on a variety of food items. The most frequently-ingested food item are detritus (HENRIQUES-OLIVEIRA et al., 2003), algae, fungal spores, 
fragments of plants, algal and animal fragments, and sponge spicules (BUTAKKA et al., 2016). According to the classification proposed by Coffman et al. (1996), chironomid larvae can be classified as scrapers, shredders, collector-gatherers, filterers, and predators. Environmental changes can be expected to modify the distribution and availability of food resources in aquatic environments and yield a change in the trophic structure of the chironomid assemblage.

FFG-based classification of aquatic invertebrate assemblages has been widely applied and is based on morphological and behavioral characteristics (CARVALHO et al., 2009; MOTTA et al., 2004; RAMÍREZ et al., 2014). This study aimed to evaluate spatial and seasonal variations in the diversity, abundance, and functional food groups of chironomid larval assemblages in two tropical streams, based on a hypothesis that the structure of FFG and the taxonomic composition of chironomid larvae are suitable predictors of environmental degradation of aquatic ecosystems.

According to Motta et al. (2004), the great importance of invertebrates in the trophic structure of tropical streams contrasts with the paucity of data in the literature about their feeding habits. Therefore, this study aimed to evaluate the spatial and seasonal variations in the composition of diet and genera of Chironomidae larvae in two streams located in south central west region of Brazil, associated with the environmental impact assessment, based on visual, physical and chemical indicators of streams. Thus, we hypothesized that anthropogenic changes influence the composition of Chironomidae larvae, through the large input of organic matter by changing the diet of these organisms.

\section{MATERIALS AND METHODS}

The study was conducted in two tropical streams with different degrees of anthropogenic impact. The Água Boa stream (22 14 ' '0.21 " S and 54 @49 '49.9 " W, 399 m altitude) has its source in an urban area, and exhibits corresponding anthropogenic effects. The Curral de Arame stream (22 12'35"S and 54 054'46.3'W, $413 \mathrm{~m}$ altitude) has a source in a rural region, and suffers less anthropogenic impact. Both streams are located in the microbasin of Água Boa in the southern state of Mato Grosso do Sul, municipality of Dourados, Brazil (Figure 1).

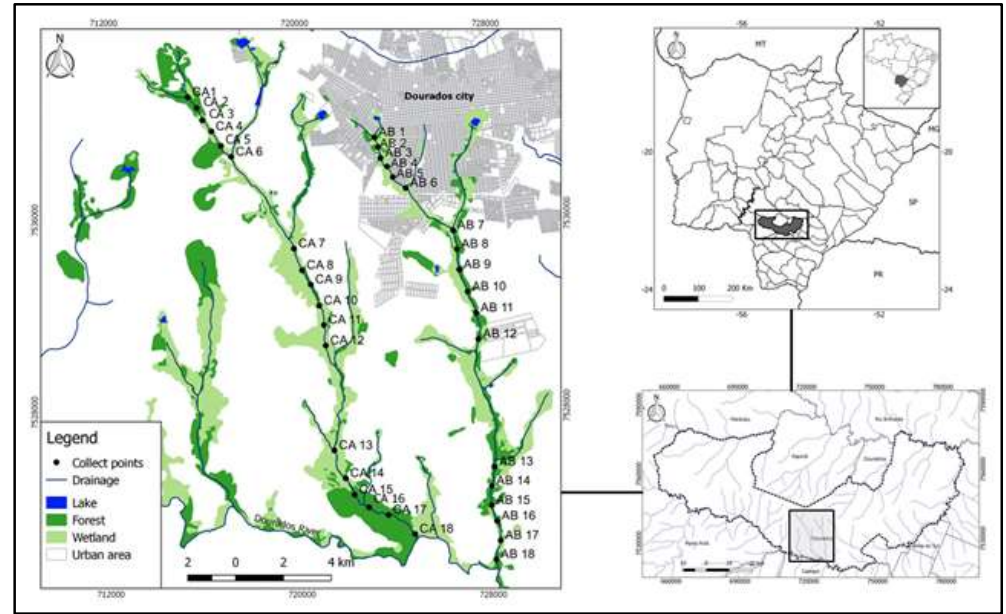

Figure 1: Map with sampling points along the Curral de Arame (CA) and Água Boa (AB) streams, located in the southern state of Mato Grosso do Sul, Dourados, Brazil. 
Sampling was performed in the dry season (DS) (May and August 2009) and wet season (WS) (November 2009 and April 2010). Three sampling sites were selected (upstream, middle and downstream), with an average distance of $9.8 \pm 5.2 \mathrm{~km}$ between sites. A $225 \mathrm{~cm}^{2}$ surber sampler with $500 \mu \mathrm{m}$ mesh size was used to collect six replicates samples at each site, totaling 18 samples per stream (Figure 1).

Environmental and anthropic indicators of each stream were evaluated using Rapid Assessment Protocol of Habitat Diversity (RAP). This protocol was developed by Callisto et al. (2002), adapted from the protocols proposed by the Environmental Protection Agency in Ohio, USA (EPA, 1987) and Hannaford et al. (1997). These protocols are based on the quantification of 22 parameters, where ten parameters evaluate the characteristics of a stretch of stream and the environmental impacts resulting from anthropic activities, and a further 11 parameters evaluate habitat conditions and conservation levels under natural conditions. The score for each parameter is attributed by observing habitat conditions: 5 points (natural environmental conditions), 3 points (slightly degraded environmental conditions), 2 points (partially degraded environmental conditions), 0 points (severely degraded environmental conditions). The final scores reflect the level of preservation of the ecological conditions of each stream area, where 0-40 points represent 'impacted' areas; 41 to 60 points represent 'altered' areas; and scores above 61 points indicate 'natural' sections.

Physical and chemical parameters including water temperature, $\mathrm{pH}$, dissolved oxygen, electrical conductivity, water turbidity, light incidence, current velocity, and flow rate were also recorded. Data were compared between streams using one-way ANOVA, in STATSOFT (2004). Collected organisms were identified to genus level using dichotomous keys (COFFMAN et al., 1996; TRIVINHO-STRIXINO, 2014), and the abundance, richness, diversity, and evenness in each sample was calculated using the Shannon-Wiener index (KENNEY et al., 2000).

In order to investigate the individual relationships between limnological variables and the chironomid assemblages, and their relationship to rapid assessment protocol data, a Canonical Correspondence Analysis (CCA) was performed using the "CCA" function of the vegan package in R (OKSANEN et al., 2018). The individual importance of the environmental descriptors was quantified using the envfit routine in $R(R$ DEVELOPMENT CORE TEAM, 2018), wherein the $r^{2}$ value for environmental and landscape metrics is obtained according toa randomization process to define the significance of these variables with 999 permutations.

To investigate diet, we examined ten stomachs of the most abundant chironomid genera per season and per stream, each of which showed relative abundance greater than $1 \%$. Gut content was analyzed using a section of the digestive tract on slides with Hoyer medium under an inverted microscope. Content was classified into five categories: fine detritus (fine particulate organic matter or FPOM), coarse detritus (coarse particulate organic matter or (POM), algae, fungi, or animal material. The classification of fine and coarse detritus was visual, based on particle size and structure (FPOM $<1 \mathrm{~mm}$ and CPOM $>1 \mathrm{~mm}$ ). Relative area (\%) occupied by each food type was estimated using an optical microscope. According to the percentage of food items present, three trophic groups were established: detritivorous, consuming FPOM (DF); detritivorous, consuming CPOM (DC); and predators, consuming animal material (PR). A Ward's cluster analysis of ingested 
food items was employed to visualize the spatial and temporal organization of chironomid larvae in relation to their diet.

\section{RESULTS}

RAP diversity scores classified the Água Boa stream as 'impacted', while the Curral de Arame stream was 'natural' (Table 1). Dissolved oxygen, conductivity, and light incidence represented strong indicators of degradation in the Água Boa stream, corroborating the RAP results (Table 1).

Table 1: Score the Protocol for Rapid Assessment of Habitat Diversity (RAP), annual mean and standard deviation of water temperature $\left({ }^{\circ} \mathrm{C}\right), \mathrm{pH}$, dissolved oxygen $\left(\mathrm{mg} \mathrm{L}^{-1}\right)$, electric conductivity $\left(\mu \mathrm{S} \mathrm{cm}^{-1}\right)$, turbidity (FTU), light incidence (LUX), current velocity $\left(\mathrm{ms}^{-1}\right)$, and flow rate $\left(\mathrm{m}^{3} \mathrm{~s}^{-1}\right)$ of the Curral de Arame and Água Boa streams.

\begin{tabular}{|l|l|l|l|l|}
\hline Parameters & Água Boa & Curral de Arame & $\mathbf{F}_{1,22}{ }^{*}$ & $\boldsymbol{p}$ \\
\hline PRA & $32 \pm 20.95$ & $78 \pm 11.79$ & 75.2 & $<0.05$ \\
\hline o C & $23.6 \pm 4.00$ & $21.2 \pm 2.97$ & 2.76 & 0.11 \\
\hline pH & $7.3 \pm 0.40$ & $7.6 \pm 0.18$ & 5.58 & $<0.05$ \\
\hline $\mathbf{m g L}^{-1}$ & $4.8 \pm 1.07$ & $7.8 \pm 0.85$ & 59.7 & $<0.05$ \\
\hline $\boldsymbol{\mu S} \mathbf{~ c m}^{-1}$ & $362 \pm 282.84$ & $52 \pm 6.68$ & 14.4 & $<0.05$ \\
\hline FTU & $21 \pm 15.11$ & $17 \pm 9.57$ & 0.56 & 0.46 \\
\hline LUX & $32.150 \pm 34.433,41$ & $4838 \pm 6104.39$ & 7.31 & $<0.05$ \\
\hline $\mathbf{m . s}^{-1}$ & $0.25 \pm 0.13$ & $0.27 \pm 0.15$ & 0.17 & 0.68 \\
\hline $\mathbf{m}^{\mathbf{3}} \mathbf{s}^{-1}$ & $0.65 \pm 1.00$ & $0.32 \pm 0.28$ & 1.2 & 0.28 \\
\hline
\end{tabular}

* One-way ANOVA significant at $p=0.05$.

We identified 28 genera of chironomid larvae in Água Boa and 30 in Curral de Arame. The genera most represented in Água Boa were Chironomus, which was dominant in both seasons, and Goeldichironomus, which dominated in the dry season (Tab. II). Despite high overall abundance in Água Boa, the richness of genera and ecological indices were relatively low. Curral de Arame showed diversity index and evenness up to four times higher than Água Boa. Although abundance values were higher in the dry season in both streams, the same was not observed for ecological indices (Table 2).

Table 2: Taxonomic composition, abundance, genus richness, diversity index $\left(\mathrm{H}^{\prime}\right)$, and eveness $\left(\mathrm{N}_{1}\right)$ of Shannon-Wiener of the chironomid larval assemblages collected in natural and impacted streams during the dry (DS) and wet (WS) seasons.

\begin{tabular}{|c|l|l|l|l|}
\hline Chironomidae & Impacted stream & \multicolumn{2}{l|}{ Natural stream } \\
\hline & Dry season & Rainy season & Dry season & Rainy season \\
\hline Subfamily Tanypodinae & & & & \\
\hline Tribe Coelotanypodini & & & & \\
\hline Clinotanypus & 0 & 0 & 0 & 2 \\
\hline Coelotanypus & 0 & 0 & 1 & 0 \\
\hline Tribe Pentaneurini & & & & \\
\hline Ablabesmyia & 323 & 262 & 60 & 12 \\
\hline Denopelopia & 7 & 0 & 1 & 1 \\
\hline Labrudinia & 1 & 0 & 0 & 0 \\
\hline Larsia & 6 & 1 & 3 & 1 \\
\hline Larsia af. & 16 & 0 & 0 & 0 \\
\hline Pentaneura & 1 & 0 & 1 & 0 \\
\hline Thienemannimyia & 36 & 0 & 1 & 0 \\
\hline Zavrelimyia & 0 & 11 & 6 & 0 \\
\hline Tribe Macropelopiini & & & & \\
\hline Brudiniella & 5 & 0 & 0 & 0 \\
\hline Tribe Procladiini & & & & \\
\hline Djalmabatista & 0 & 0 & 22 & 17 \\
\hline Procladius & 0 & 0 & 3 & 0 \\
\hline Subfamily Chironominae & & & \\
\hline
\end{tabular}




\begin{tabular}{|c|c|c|c|c|}
\hline \multicolumn{5}{|l|}{ Tribe Chironomini } \\
\hline Axarus & 1 & 0 & 0 & 0 \\
\hline Chironomus & 10248 & 1387 & 1 & 0 \\
\hline Cryptochironomus & 10 & 11 & 9 & 2 \\
\hline Dicrotendipes & 0 & 4 & 0 & 1 \\
\hline Endotribelos & 0 & 2 & 0 & 0 \\
\hline Goeldichironomus & 5234 & 34 & 33 & 5 \\
\hline Harnischia & 0 & 1 & 1 & 0 \\
\hline Microtendipes & 1 & 0 & 0 & 0 \\
\hline Polypedilum & 209 & 98 & 0 & 0 \\
\hline Parachironomus & 0 & 25 & 10 & 36 \\
\hline Tribelos & 0 & 0 & 7 & 3 \\
\hline Saetheria & 0 & 0 & 0 & 3 \\
\hline Stenochironomus & 0 & 1 & 18 & 7 \\
\hline Zavreliella & 0 & 0 & 1 & 0 \\
\hline \multicolumn{5}{|l|}{ Tribe Pseudochironomini } \\
\hline Pseudochironomus & 1 & 0 & 0 & 0 \\
\hline \multicolumn{5}{|l|}{ Tribe Tanytarsini } \\
\hline Caladomyia & 0 & 0 & 28 & 6 \\
\hline Tanytarsus & 0 & 1 & 58 & 3 \\
\hline Rheotanytarsus & 857 & 1807 & 16 & 16 \\
\hline Stempellina & 0 & 0 & 1 & 0 \\
\hline \multicolumn{5}{|l|}{ Subfamily Orthocladiinae } \\
\hline \multicolumn{5}{|l|}{ Tribe Corynoneurini } \\
\hline Corynoneura & 20 & 0 & 3 & 1 \\
\hline Onconeura & 387 & 693 & 6 & 13 \\
\hline \multicolumn{5}{|l|}{ Tribe Orthocladiini } \\
\hline Cricotopus & 211 & 193 & 5 & 2 \\
\hline Lopescladius & 0 & 0 & 21 & 19 \\
\hline Nanocladius & 2 & 0 & 2 & 0 \\
\hline Rheocricotopus & 0 & 0 & 11 & 11 \\
\hline Abundance & 17.576 & 4.531 & 329 & 161 \\
\hline Genus richness & 20 & 16 & 27 & 20 \\
\hline Diversity $\left(\mathrm{H}^{\prime}\right)$ & 1.12 & 1.51 & 2.69 & 2.51 \\
\hline Eveness $\left(\mathrm{N}_{1}\right)$ & 0.37 & 0.54 & 0.81 & 0.84 \\
\hline
\end{tabular}

The results of the canonical correspondence analysis suggest that $62.9 \%$ of the variation in the dry season is explained by the first two axes of the CCA, with the first axis explaining $40.8 \%$ and the second explaining $22.1 \%$. Dissolved oxygen was the most important factor in determining the occurrence of chironomid genera, followed by electrical conductivity, $\mathrm{pH}$, temperature, and degree of anthropogenic impact as measured by RAP (Table 3, Figure 2). In the rainy period, the results of the analysis suggest that $63.4 \%$ of the data variation in the rainy season is explained by the first two axes of the CCA, with the first axis explaining $38.8 \%$ and the second axis explaining $24.55 \%$. Temperature was the most important factor in determining the occurrence of chironomid genera, followed by $\mathrm{pH}$ and dissolved oxygen (Table 3, Figure 3).

Table 3: Canonical Correspondence Analysis (CCA) results showing individual influences of limnological variables and level of anthropogenic impact on chironomid assemblages.

\begin{tabular}{|c|c|c|c|c|c|c|}
\hline & \multicolumn{3}{|c|}{ Dry Season } & \multicolumn{3}{|c|}{ Rainy Season } \\
\hline Physicochemical variables & Axis 1 & Axis 2 & $r^{2}$ & Axis 1 & Axis 2 & $r^{2}$ \\
\hline Temperature (으) & -0.97 & 0.24 & 0.73 & -0.49 & 0.86 & $0.93 * *$ \\
\hline $\mathrm{pH}$ & 0.93 & 0.37 & 0.74 & 0.41 & -0.91 & $0.86^{*}$ \\
\hline Dissolved oxygen (mg. $\left.\mathrm{L}^{-1}\right)$ & 0.98 & 0.16 & 0.85 & 0.99 & -0.11 & $0.82 *$ \\
\hline Conductivity $\left(\mu \mathrm{s} . \mathrm{cm}^{-1}\right)$ & -0.96 & -0.26 & 0.75 . & -0.94 & -0.32 & 0.80 \\
\hline Turbidity (NTU) & -0.33 & 0.94 & 0.67 & -0.32 & 0.94 & 0.29 \\
\hline Luminosity (LUX) & -0.99 & 0.13 & 0.59 & -0.41 & 0.91 & 0.72 \\
\hline Velocity $\left(\mathrm{m} . \mathrm{s}^{-1}\right)$ & 0.56 & -0.82 & 0.56 & -0.77 & -0.62 & 0.44 \\
\hline
\end{tabular}




\begin{tabular}{|l|l|l|l|l|l|l|}
\hline RAP & 0.99 & -0.01 & 0.71 & 0.75 & -0.66 & 0.56 \\
\hline Statistical summary of the axes 1 and 2 & $40.87 \%$ & $22.12 \%$ & & $38.85 \%$ & $24.55 \%$ & \\
\hline Percentage Explanation (\%) &
\end{tabular}

* indicates significance at $\alpha=0.05 ; * * *$ indicates significance at $\alpha=0.001$

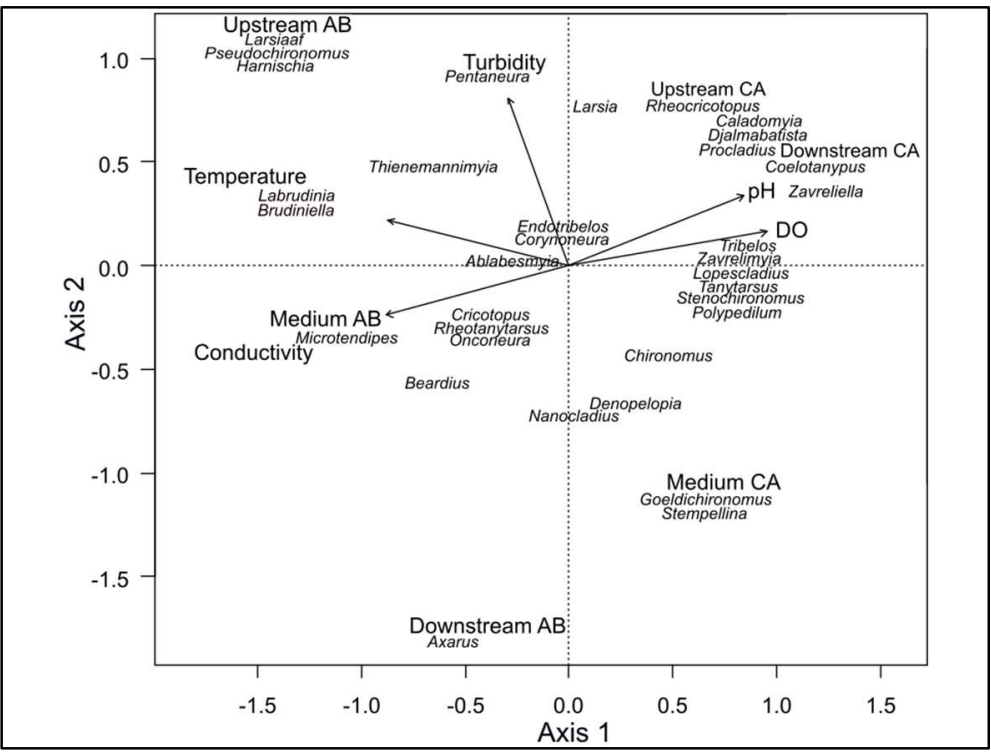

Figure 2: Canonical Correspondence Analysis (CCA) results showing individual influence of limnological variables and level of anthropogenic impact on chironomid larval assemblages in dry season.

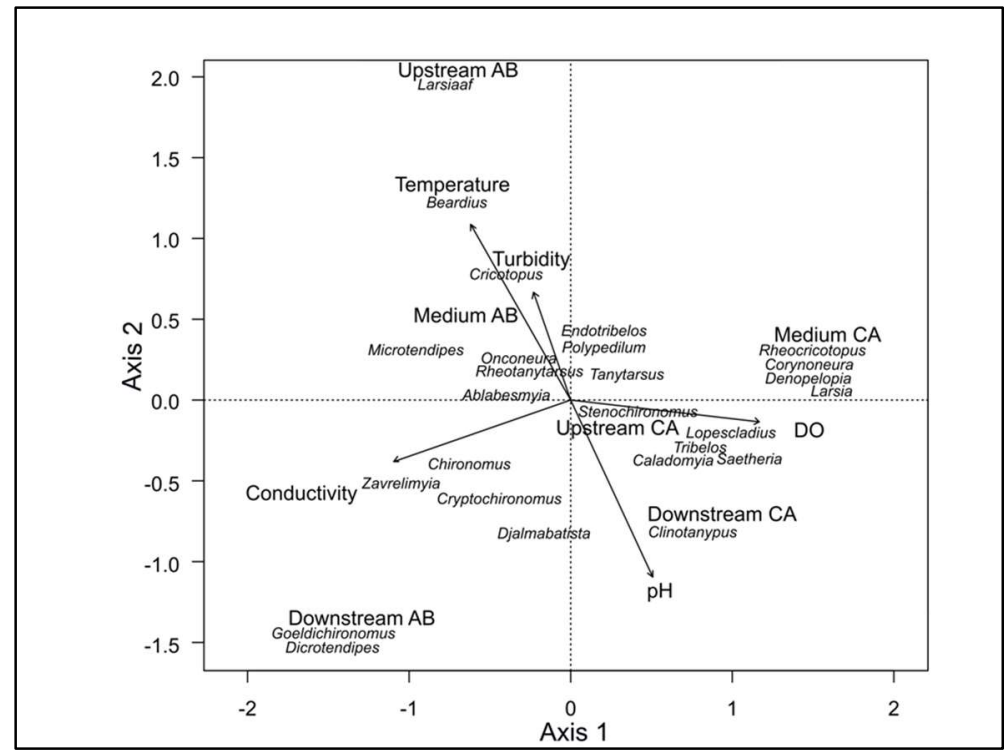

Figure 3: Canonical Correspondence Analysis (CCA) results showing individual influence of limnological variables and level of anthropogenic impact on chironomid larval assemblages in rainy season.

Fine particulate organic matter was the main food item consumed by chironomid larvae in both streams (Figure 4). The genera Onconeura, Rheotanytarsus, and Polypedilum, sampled in both streams and seasons, consumed predominantly fine detritus associated with algae, fungi, coarse detritus, and animal material. The genus Stenochironomus preferentially ingested coarse particulate organic matter and was sampled only in the natural stream. Rheocricotopus was also sampled only in the natural stream, and showed feeding plasticity by consuming fine detritus in the dry season and coarse detritus in the wet season. Animal fragments were mainly consumed by Djalmabatista and Ablabesmyia. The latter exhibited some plasticity around this habit, consuming food of animal origin in the impacted stream and fine particulate organic matter associated with algae, fungi, and animal material in the natural stream. 


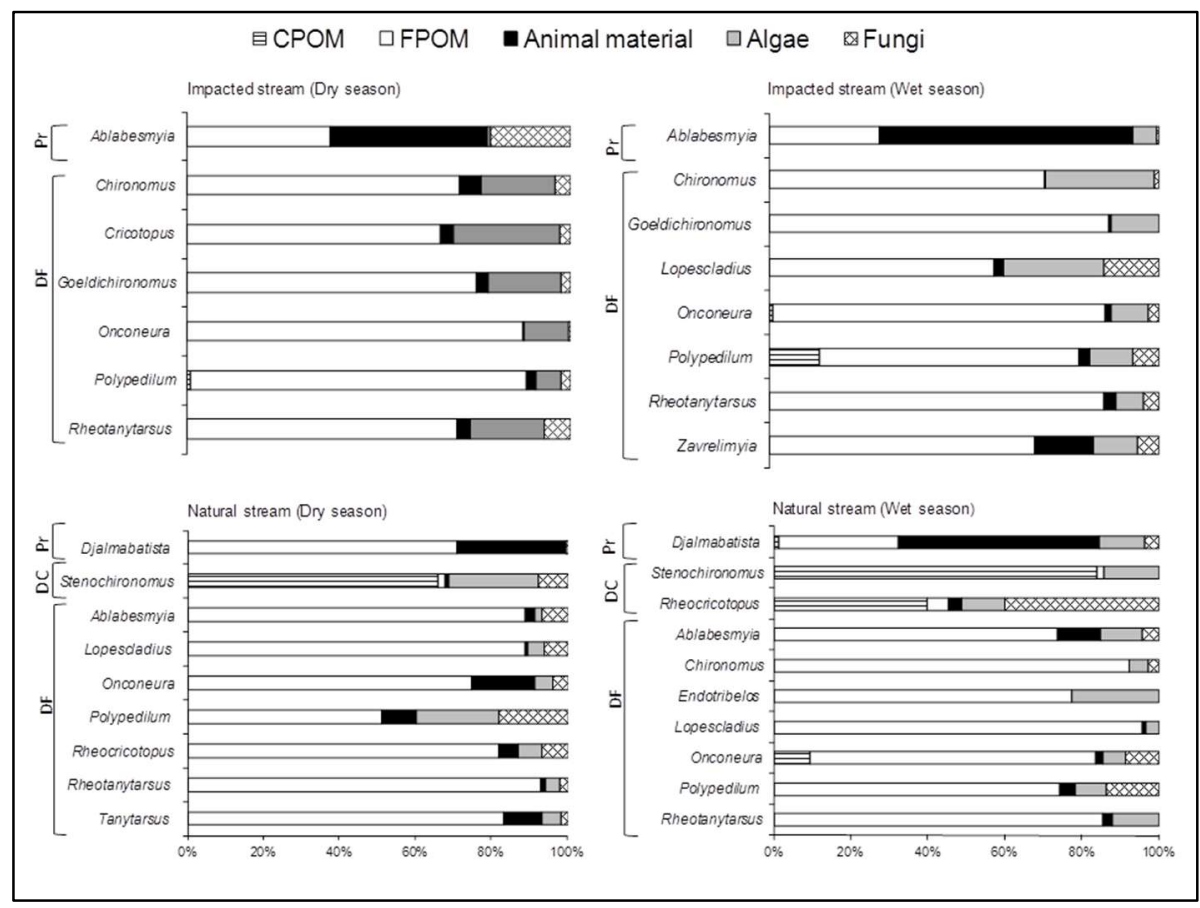

Figure 4: Percentage of food items recorded in the diets of the most abundant chironomid genera according to stream and season. Abbreviations indicate the following trophic groups: predators (Pr), detritivores of FPOM (DF), and detritivores of CPOM (DC).

Cluster analysis (Fig. 5) indicated three trophic groups: 1) detritivorous consuming predominantly or exclusively fine particulate organic matter, representing $82 \%$ of the genera analyzed; 2 ) predators consuming mainly animal fragments, and 3) detritivorous consuming coarse particulate organic matter, which together accounted for $18 \%$ of the genera sampled.

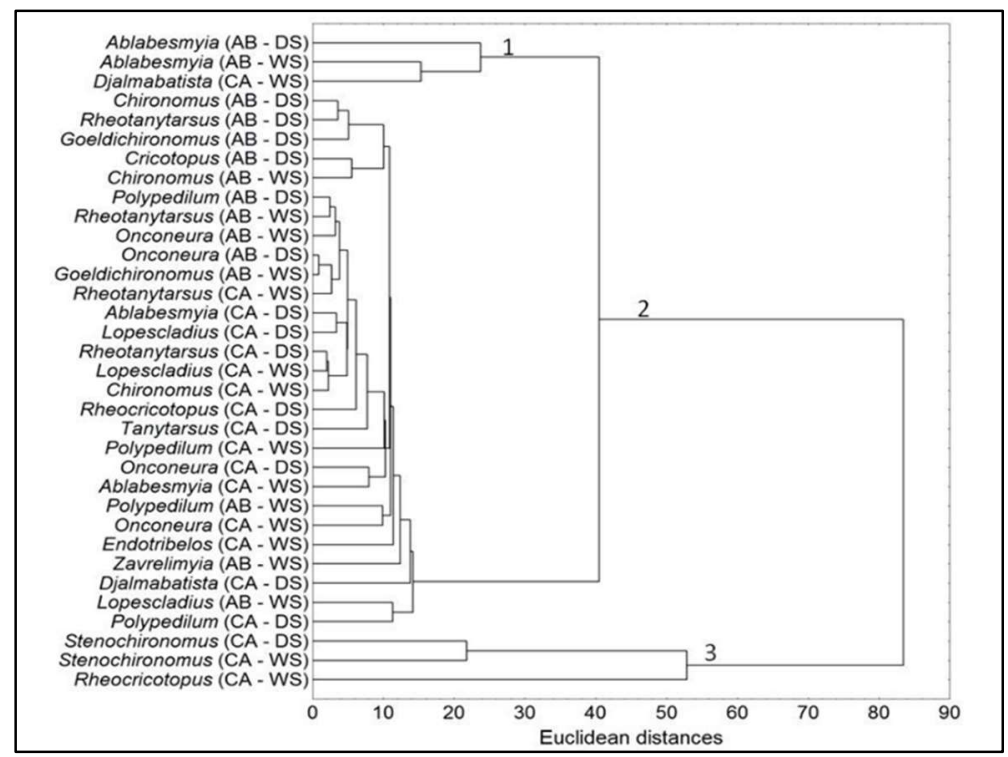

Figure 5: Results of the hierarchical cluster analysis (group average) applied to the diet of chironomid genera most abundant in Água Boa (AB) and Curral de Arame streams (CA) in the dry (DS) and wet (WS) seasons. Trophic groups include (1) Predators, (2) Detritivores of FPOM, and (3) Detritivores of CPOM.

\section{DISCUSSION}

The RAP results corroborated physical and chemical data from the streams. Physical and chemical parameters such as dissolved oxygen, conductivity, and light incidence showed values reflecting the input of pollutants and degradation of impacted Água Boa stream. Dissolved oxygen, for example, was repeatedly 
observed to be below the limit of $5 \mathrm{mg} \mathrm{L}^{-1}$ specified by current legislation in the Conselho Nacional do Meio Ambiente (CONAMA, or National Council of the Environment) in its Resolution No. 357/05, which establishes classification of fresh, brackish and saline waters of the National Territory. Depleted dissolved oxygen is directly or indirectly related to high organic loading in the stream, which increases the density and metabolism of decomposing aerobic microorganisms. A similar pattern was observed for the high values of electrical conductivity of the water, which may be also indicative of decomposition and input of organic and inorganic compounds in the stream. Meanwhile, high incident light indicated the existence of large deforested areas. Riparian vegetation has the important function of blocking the direct incidence of light, serving as habitats for organisms, providing food through the input of allochthonous material (leaves, flowers, seeds, among others), retention of the stream margins, and filtration of agrochemicals and other pollutants from adjacent areas (CARVALHO et al., 2009; MOSISCH et al., 2001).

In comparing the observations of physical and chemical characteristics, we found that the occurrence and diversity of chironomid larvae were also strong indicators of environmental quality. The sampled organisms showed the lowest diversity and evenness in the impacted stream and consequent dominance of Chironomus and Goeldichironomus. These show a preference for sites with humic and fulvic compounds, and are commonly found in environments with organic matter input and correspondingly depleted dissolved oxygen (CHAIB et al., 2012; RAWAL et al., 2014). They are considered key indicators of negative impacts in aquatic environments, both in terms of their occurrence and in their dominance over other genera. As such, they indicate the classification of the river, water quality, and the effects of natural and anthropogenic disturbances (HELSON et al., 2006).

The greatest abundance of chironomid larvae was recorded in the dry season in both streams, possibly due to the higher stability of the substrate during this period. Other studies have also shown the existence of a seasonal pattern in the aquatic invertebrate community structure, with a trend towards greater abundance during dry seasons (EADY et al., 2014). Seasonal patterns can be the result of a number of interdependent factors, including interactions between intrinsic characteristics of the environment and climatic factors in the region. These factors should be better understood so that they are not interpreted as an indicator of environmental imbalance or degradation. Moreover, knowledge of seasonal variations may be important for evaluating other factors related to the structure of the aquatic invertebrate community, such as the diet of chironomid larvae. Seasonal changes are responsible for the availability of energy resources in the stream, and may influence the diet of some taxa. Structural changes associated with drought such as the reduction of canopy cover and rates of decomposition may lead to changes in the functional composition of chironomid assemblages (CAÑEDO-ARGÜELLES et al., 2016).

FFG classifications based on gut content indicated that the impacted stream did not contain specialists in coarse particulate organic matter (CPOM). Other work has shown that the absence of specialist organisms, such as detritivorous shredders, may indicate environmental degradation (CARVALHO et al., 2009). In the natural stream, the presence of specialist shredders Stenochironomus and Rheocricotopus, associated with forested streams, indicates the good condition of the stream. These aspects of the 
environment are evident in visual observation, as well as the high values of richness, diversity, and evenness of chironomids. This suggests that the composition and feeding habits of chironomids depend on environmental conditions related to anthropogenic changes affecting aquatic ecosystems.

The assemblage of chironomids with different feeding habits was also affected by the state of anthropogenic degradation in the streams. Detritivorous consumers ingesting primarily CPOM are commonly classified as shredders, converting thin organic material into substrate and food for other organisms (COFFMAN et al., 1996; TONIN et al., 2014). Shredders and collectors are the major primary consumers in forested streams, providing the main link between coarse organic matter and invertebrate predators (CHESHIRE et al., 2005). In our study, we observed only Stenochironomus shredders in the dry season. In the wet season, we observed dietary CPOM reflective of shredding behavior in both Stenochironomus and Rheocricotopus, which was observed as detritivorous of FPOM in the dry season. Stenochironomus feeds mainly on leaves and wood fragments, with cells and fibers of the plant material observable in its stomach contents (HENRIQUES-OLIVEIRA et al., 2003). Its distribution is closely related to the integrity of riparian vegetation, as it is largely dependent on leaves in the stream bed. As such, shredders are very vulnerable to deforestation (BENSTEAD et al., 2004; BAXTER et al., 2005; YOSHIMURA, 2012) and likely represent key indicators of environmental degradation.

Meanwhile, fine particulate organic matter (FPOM) was the most abundant food resource found in gut contents of other larvae, classifying them as specialist or generalist detritivores. This group has a low degree of selectivity and more generalist habits, and is present in high densities in combination with debris (MOTTA et al., 2004). This allows its direct or indirect participation in the process of decomposition (BIASE et al. 2013). Furthermore, the group's abundance is correlated with the amount of FPOM generally present in areas of deposition inlower order streams (CALLISTO et al., 2013). In our study, FPOM was mostly found associated with other items such as algae, fungi, animal fragments and CPOM. Animals feeding on a combination of algae, organic matter, and microbiota by scraping submerged surfaces such as rocks, trunks, and macrophytes are classified as consumers of periphyton (MOTTA et al., 2004). According to Coffman et al. (1996), these animals can be classed as herbivores or detritivores within the functional group of scrapers. However, we were unable to utilize this classification due to the low proportion of algae and fungi observed in gut contents.

The natural stream hosted two genera of chironomid predators, Ablabesmyia and Djalmabatista, while the impacted stream hosted only Ablabesmyia. They are classifiable as predators based on ingested animal fragments (HENRIQUES-OLIVEIRA et al., 2003), with samples in our study exhibiting other whole chironomids and cephalic parts in their gut contents. However, we could not confirm cannibalism based on genera. Coffman et al. (1996) classified this feeding habit as engulfment predation. The quantity of animal fragments consumed per Ablabesmyia individual was higher in the impacted stream, which can be explained by the high density of chironomids in this environment. In the natural stream, we observed smaller amounts of animal fragment in gut contents of this genus. In addition to low prey density, Ablabesmyia also competes for the same food as Djalmabatista. In this case, the trophic niche overlap may influence the proportion of 
food items ingested by these genera.

Chironomid larvae showed spatial and seasonal variations, with the presence of two predatory genera in the natural stream and only one in the impacted stream, and greater abundance in the dry season for both streams. Both streams also showed detritivorous chironomids as the main trophic group, demonstrating the importance of organic matter as a source of food for this family, as reported by Carvalho et al. (2009). However, the impacted stream showed considerably greater abundance than the natural stream, indicating that the composition of chironomid larvae is influenced by anthropic changes through the input of organic matter and altering taxonomic composition and stability of chironomid community, as reflected in the high density and dominance of Chironomus and Goeldichironomus.

Therefore, understanding the negative effects of human pressure on the community of chironomid larvae helps to define measures for the conservation and recovery of aquatic ecosystems, since these organisms participate in the cycling of nutrients and trophic interactions, constituting an important food source for other organisms. This taxonomic group proved to be the link between basal resources and secondary consumers. Thus, alterations in the input of basal resources, caused mainly by anthropic pressures, could significantly affect the assemblages of Chironomidae.

\section{CONCLUSIONS}

This study demonstrates that chironomid larvae respond to anthropogenic changes with modified community composition, wherein shredding detritivores are lost. Such biological indicators are also supported by abiotic indicators, as can be observed through visual analysis of the environment and physical and chemical parameters. The analysis of diet in the characterization of trophic groups proved to be a useful complementary tool for determining indicators of anthropogenic changes, and could be applied in assessing and restoring degraded areas. The study of functional food groups is also a useful approach, since it permits surveillance of environmental impacts without necessarily requiring more refined taxonomic identification.

ACKNOWLEDGEMENTS: The authors wish to express their gratitude to UEMS, for the PIBIC scholarship, to FUNDECT for their assistance in the research of the Regional Scientific Development project (DCR FUNDECT/CNPq) of the advisor to this study, and to colleagues and professors of EBI for assistance in the identification of chironomids.

\section{REFERENCES}

BAXTER, C.V.; FAUSCH, K. D; SAUNDERS, W. C.. Tangled webs: reciprocal flows of invertebrate prey link stream and riparian zones. Freshwater Biology, v.50, n.2, p.201-220, 2005.

BENSTEAD, J. P.; PRINGLE, C. M.. Deforestation alters the resource base and biomass of endemic stream insects in eastern Madagascar. Freshwater Biology, v.49, n.4, p.490501, 2004
BIASI, C.; TONIN, A. M.; RESTELLO, C. R. M.; HEPPC, L. U.. The colonisation of leaf litter by Chironomidae (Diptera): The influence of chemical quality and exposure duration in a subtropical stream. Limnologica: Ecology and Management of Insland Waters, v.43, p.427-433, 2013.

BUTAKKA, C. M. M.; RAGONHA, F. H.; TRAIN, S.; PINHA, G. D.; TAKEDA, A. M.. Chironomidae feeding habits in different habitats from a Neotropical floodplain: exploring patterns in aquatic food webs. Brazilian Journal of Biology, v.76, n.1, 
p.117-125, 2016. DOI: http://dx.doi.org/10.1590/1519$\underline{6984.14614}$

CALIZZA, E.; COSTANTINI, M. L.; ROSSI, D.; CARLINO, P.; ROSSI, L.. Effects of disturbance on an urban river food web. Freshwater Biology, v.57, n.12, p.2613-2628, 2012.

CALLISTO, M.; GRAÇA, M. A. S.. The quality and availability of fine particulate organic matter for collector species in headwater streams. International Review of Hydrobiology, v.98, p.132-140, 2013.

CAÑEDO-ARGÜELLES, M.; BOGANC, M. T.; LYTLED, D. A.; PRAT, N.. Are Chironomidae (Diptera) good indicators of water scarcity? Dryland streams as a case study. Ecological Indicators, n.71, p.155-162, 2016. DOI: http://dx.doi.org/10.1016/j.ecolind.2016.07.002

CARVALHO, E.M; UIEDA, V. S.. Diet of invertebrates sampled in leaf-bags incubated in a tropical headwater stream. Revista Brasileira de Zoologia, v.26, n.4, p.694-704, 2009.

CHAIB, N.; BOUHALA, Z.; FOUZARI, L.; MARZIALI, L.; SAMRAOUI, B.; ROSSARO, B.. Environmental factors affecting the distribution of Chironomid larvae of the Seybouse wadi, North-Eastern Algeria. Journal of Limnology, v.72, n.2, p.03214, 2013. DOI: http://dx.doi.org/10.4081/jlimnol.2013.e16

CHESHIRE, K.; BOYERO, L.; PEARSON, R. G.. Food webs in tropical Australian streams: shredders are not scarce. Freshwater Biology, v.50, n.5, p.748-769, 2005.

CHOUDHARY, A.; AHI, J.. Biodiversity of Freshwater Insects: A Review. The International Journal of Engineering and Science, v.4, p.10, p.25-31, 2015.

COFFMAN, W. P.; FERRINGTON, L. C.. Chironomidae. In: MERRIT, K. W.; CUMMINS, R. W.. An introduction of aquatic insects of North America. Dubuque: Kendall Hunt Publishing Company. 1996. p.635-754.

EADY, B. R.; HILL, T.R.; NICK, A.; MOORE, R.. Shifts in aquatic macroinvertebrate community structure in response to perenniality, southern Cape, South Africa. Journal of Freshwater Ecology, v.29, n.4, p.475-490, 2014.

EPA. Environmental protection agency. Biological criteria for the protection of aquatic life. Columbus: Division of Water Quality Monitoring Assessment, 1987.

HANNAFORD, M. J; BARBOUR, M. T.; RESH, V. H.. Training reduces observer variability in visual based assessments of stream habitat. Journal of the North American Benthological Society, v.16, n.4, p.853-60, 1997.

HELSON, J. E.; WILLIAMS, D. D.; TURNER, D.. Larval chironomidae community organization in four tropical rivers: human impacts and longitudinal zonation. Hydrobiology, v.559, p.413-431, 2006.

HENRIQUES-OLIVEIRA, A. L.; NESSIMIAN, J. L.; DORVILLÉ, L. F. $M$.. Feeding habits of Chironomid larvae (insecta: diptera) from a stream in the Floresta da Tijuca, Rio de Janeiro, Brazil. Acta Limnologica Brasiliensia, v.15, n.2, p.69-84, 2003.
KENNEY, A. J.; KREBS, C. J.. Programs for ecological methodology: version 5.2. 2 ed. Vancouver, University of British Columbia, 2000.

LENCIONI, V.; MARZIALI, L.; ROSSARO, B.. Chironomids as bioindicators of environmental quality in mountain springs. Freshwater Science, v.31, n.2 p.525-541, 2012. DOI: https://doi.org/10.1899/11-038.1

MOSISCH, T. D.; BUNN, S. E.; DAVIES, P. M.. The relative importance of shading and nutrients on algal production in subtropical streams. Freshwater Biology, v.46, p.1269-1278, 2001.

MOTTA, R. L.; UIEDA, V. S.. Diet and trophic groups of in aquatic insect community in a tropical stream. Brazilian Journal of Biology, v.64 n.4 p.809-817, 2004.

OKSANEN, J.; BLANCHET, F. G.; KINDT, R.; LEGENDRE, P.; O'HARA, R. B.; SIMPSON, G. L.; STEVENS, M. H. H.; WAGNER, H.. Vegan: Community Ecology Package. 2018.

R DEVELOPMENT CORE TEAM. R: A language and environment for statistical computing. Vienna: R Foundation for Statistical Computing, 2018.

RAMÍREZ, A.; GUTIÉRREZ-FONSECA P. E.. Functional feeding groups of aquatic insect families in Latin America: a critical analysis and review of existing literature. Journal of Tropical Biology, v.62, n.2, p.155-67, 2014.

RAWAL, D.. Ecological analysis of Chironomus larvae (Diptera: Chironomidae) collected from Ayad River in Udaipur City. International Journal of Fauna and Biological Studies, v.1 n.5, p.20-21, 2014

REZENDE, R. S.; NOVAES. J. L. C.; ALBUQUERQUE, C. Q.; COSTA, R. S.; JUNIOR, J. F. G.. Aquatic invertebrates increase litter breakdown in Neotropical shallow semi-arid lakes. Journal of Arid Environments, v.158, p.8-14, 2018. DOI: http://doi.org/10.1016/j.jaridenv.2018.03.002

SERRA, S. R. Q.; COBO, F.; GRAÇA, M. A. S.; DOLÉDEC, S.; FEIO, M. J.. Synthesising the trait information of European Chironomidae (Insecta: Diptera): Towards a new database. Ecological Indicators, v.61 p.282-292, 2016.

TEJERINA, E. G.; MALIZIA, A.. Chironomidae (Diptera) larvae assemblages differ along an altitudinal gradient and temporal periods in a subtropical montane stream in Northwest Argentina. Hydrobiology, v.686, p.41-54, 2012.,

TONIN, A. M.; HEPP, L. U.; RESTELLO, R. M.; GONÇALVES JUNIOR, J. F.. Understanding of colonization and breakdown of leaves by invertebrates in a tropical stream is enhanced by using biomass as well as count data. Hydrobiology v.740 p.79-88, 2014

TRIVINHO-STRIXINO, S.. Ordem Diptera. Família Chiromidae. Guia de identificação de larvas. In: HAMADA, N.; NESSIMIAN, J. L.; QUERINO, R. B.. Insetos aquáticos na Amazônia brasileira: taxonomia, biologia e ecologia. Manaus: INPA, 2014. p.457-660.

VANNOTE, R. L.; MINSHALL, G. W.; CUMMINS, K. W.; SEDELL, J. R.; CUSHING, C. E.. The river continuum concept. Canadian 
Journal of Fisheries and Aquatic Sciences, v.37, p.130-137, 1980.

WWAP. United Nations World Water Assessment Programme. The United Nations World Water Development
Report 2018: Nature-Based Solutions for Water. Paris: UNESCO, 2018.

YOSHIMURA, M.. Effects of forest disturbances on aquatic insect assemblages. Entomology Sciences, v.15, p.145-154, 2012.

A CBPC - Companhia Brasileira de Produção Científica (CNPJ: 11.221.422/0001-03) detém os direitos materiais desta publicação. Os direitos referem-se à publicação do trabalho em qualquer parte do mundo, incluindo os direitos às renovações, expansões e disseminações da contribuição, bem como outros direitos subsidiários. Todos os trabalhos publicados eletronicamente poderão posteriormente ser publicados em coletâneas impressas sob coordenação da Sustenere Publishing, da Companhia Brasileira de Produção Científica e seus parceiros autorizados. Os (as) autores (as) preservam os direitos autorais, mas não têm permissão para a publicação da contribuição em outro meio, impresso ou digital, em português ou em tradução. 